REGULAR ARTICLE

\title{
ANTIBACTERIAL ACTIVITY OF ETHANOL CRUDE EXTRACTS OF WHOLE PLANT OF THE UGANDAN PHYLLANTHUS AMARUS SCHUMACH. \& THONN AGAINST SHIGELLA DYSENTERIAE
}

\author{
Magimbi Arthur ${ }^{l}$, Adamu Almustapha Aliero ${ }^{2,3 *}$ and John Odda ${ }^{l}$ \\ Address (es): Mr. Adamu Almustapha Aliero, \\ ${ }^{1}$ School of Pharmacy, Kampala International University Western Campus, Uganda. \\ ${ }^{2}$ Departments of Microbiology and Immunology, Kampala International University Western Campus, Uganda \\ ${ }^{3}$ Department of Microbiology, Faculty of Life Sciences, Kebbi State University of Science and Technology Aliero, Kebbi State, Nigeria. \\ *Corresponding author: aimustapha.adamu@kiu.ac.ug, adamualieroa@gmail.com
}

\begin{abstract}
Apart from being used for the treatment of malaria fevers, mono-herbal preparation of Ugandan Phyllanthus amarus is widely by local communities in central Uganda, for treatment of bacterial dysentery. However, efficacy studies regarding the mono-herbal extracts of the Ugandan Phyllanthus amarus against Shigella dysenteriae is lacking. The present study was aimed at determined the antibacterial activity of aqueous ethanol crude extracts of whole plant of Phyllanthus amarus against Shigella dysenteriae. Whole plant of Phyllanthus amarus was collected from Wakiso district central of Uganda. Different concentrations $\left(128 \mu \mathrm{g}\right.$. $\mathrm{mL}^{-1}, 256 \mu \mathrm{g} . \mathrm{mL}^{-1}$ and $512 \mu \mathrm{g} \cdot \mathrm{mL}^{-1}$ ) of the ethanol crude extract of whole plant of Phyllanthus amarus were tested against Shigella dysenteriae using agar well diffusion method. Minimum inhibitory concentration (MIC) was determined using broth tube dilution method while Minimum bactericidal concentration (MBC) was determined by culture method. The results of this study showed that, Shigella dysenteriae was sensitive to different concentrations $\left(128 \mu \mathrm{g} \cdot \mathrm{mL}^{-1}, 256 \mu \mathrm{g} \cdot \mathrm{mL}^{-1}\right.$ and $\left.512 \mu \mathrm{g} \cdot \mathrm{mL}^{-1}\right)$ of ethanol crude extract of whole plant of Phyllanthus amarus possessed antibacterial against Shigella dysenteriae with mean and standard error mean zone of inhibition ranging from $11.5 \pm 0.5$ to $13.5 \pm 0.5 \mathrm{~mm}$, while the positive control had mean and standard error mean zone of inhibition $24.5 \pm 0.5 \mathrm{~mm}$. The MIC and MBC of the ethanol crude extract of whole plant of Phyllanthus amarus against Shigella dysenteriae was found to be $32 \mu \mathrm{g} \cdot \mathrm{mL}^{-1}$ and $64 \mu \mathrm{g} . \mathrm{mL}^{-1}$ respectively. This study found that the whole plant of phyllanthus amarus of ethanol crude extract was active against Shigella dysenterie. Further study should be carried out test whole plant Phyllanthus amarus crude extract on different microorganisms that cause dysentery to find out its activity against them and spectrum, determine lead compound in the whole plant Phyllanthus amarus crude extract responsible for the anti-microbial activity against Shigella dysenteriae and also determine the mechanism of action by which this plant crude extract inhibits Shigella dysenteriae.
\end{abstract}

Keywords: Antibacterial activity, whole plant of Phyllanthus amarus and Shigella dysenteriae

\section{INTRODUCTION}

The use of medicinal plants as alternative medicine is currently being given more attention worldwide (Flora and Folasade, 2008; WHO, 2017). In Africa, traditional herbal medicines are widely used informed of concoction in hot or cold water, foods and drinks for the treatment of many infectious diseases including dysentery caused by bacteria and non-bacterial agents (Senjobi $\boldsymbol{e t}$ al., 2017). Antibiotic resistant organisms have created a global threat as far as management of many diseases especially among immunocompromised patient (UNAS, 2015; WHO, 2017; CDC, 2017). Worldwide, the burden of infections caused by Shigella spp was estimated to be $80-165$ million cases of disease and 600,000 deaths annually (CDC, 2017). In Uganda, the burden of infections caused by all bacteria was reported to be $20 \%$ including dysentery caused by shigellae (UNAS, 2015). The burden of antibiotics resistance caused by Shigella spp in Uganda was established by some researchers (UNAS, 2015). In studies conducted between 1997-2007 from different part of the country (Legros $\boldsymbol{e t}$ al.,1998; Mpairwe, 2000; Atwiine , 2007; Kajumbula, 2014) showed that, Shigella isolates were resistance to most commonly prescribed antibiotics between 36 and $100 \%$ to chloramphenicol, ampicillin and co-trimoxazole, but remained lower - between 0 and $<3 \%$ (in three of the four studies) - to quinolones. These showed the needs for new, safe and chief antimicrobial agent(s) against Shigella spp. Literatures have shown that Phyllanthus amarus is used in many countries to treat different diseases. In Africa like Nigeria, Senjobi et al., 2017, reported that, Phyllanthus amarus is used in treatment of gonorrhea, genito-urinary diseases, asthma, diabetes, typhoid fever, jaundice, stomach ache, dysentery, hypertension ringworm and ophthalmic condition. Furthermore, Ogunjobi and Abiala, 2013 reported that the leave of this plant is used in the treatment of stomach pains and haemorrhoids in Kenya and Southwestern Nigeria respectively. Odda and colleagues reported this herb as being used locally to treat malaria fevers in Tororo, Eastern Uganda (Odda $\boldsymbol{e t}$ al., 2018). In central Uganda, Phyllanthus amarus (In Luganda local language called Nakitembe/Kabalira mugongo) is used for treatment of bacterial dysentery and this is done by boiling fresh leaves of Phyllanthus amarus in water for about 30 minutes and when cool the patient is given the resultant soup orally amounting to mug cup of about $500 \mathrm{ml}$ twice a day for about a week. Despite the wide herbal use of Phyllanthus amarus in the treatment of diarrheal diseases to include dysentery there is a lack of scientific publication as to its efficacy against dysentery caused by Shigella dysenteriae. The present work was aimed to determine the antibacterial activity of whole plant of Phyllanthus amarus ethanol crude extract against Shigella dysenteriae.

\section{MATERIALS AND METHODS}

\section{Study design/area and Plant collection}

This was experimental laboratory study that determined Phyllanthus amarus ethanol crude extract activity on Shigella dysenteriae. The study was conducted in January - April 2018 at Kampala International Teaching Hospital Western Campus (KIUTH-WC) microbiology laboratory and pharmacology laboratories. The study was conducted according Clinical Laboratory Standard Institute (CLSI, 2009; 2018)

The fresh whole plant of Phyllanthus amarus was collected in January, 2018 from Wakiso district central Uganda $\left(00^{\circ} 24^{\prime} \mathrm{N} 32^{\circ} 29^{\prime} \mathrm{E}\right)$ where it grows naturally in a banana garden according to the method described by (Sekar $\boldsymbol{e t}$ al., 2012).

\section{Drying and pulverization whole plants of Phyllanthus amarus}

The collected herb sample was washed, chopped in small pieces and dried in a shade to avoid direct sunshine that could degrade phytochemical due to ultra violet light because the active is not known. The herbs were air dried at room temperature by displaying it on a dry cemented table in pharmacology lab and it was turned daily to prevent fungal attack until complete dryness that was confirmed by weighing every week for three weeks and the constant weight was achieved then the plant was confirmed dry. The dried sample was ground into powder by grinding it using a blender (Md. Murad et al., 2006).

\section{Extraction of whole plant of Phyllanthus amarus}

The plant extracts was prepared by using the method of (Alade and Irobi 1993; Bhasha et al., 2014). Extraction was performed by macerating air-dried, powdered of Phyllanthus amarus in 70\% ethanol. The ground whole Plant material was weighed, the initial weight of powder was $375 \mathrm{~g}$ and it was soaked 
in 3.7 liters of $70 \%$ ethanol and put on a mechanical shaker for $72 \mathrm{~h}$. After $72 \mathrm{~h}$ of agitation on mechanical shaker, the mixture was sieved using a clean sieve and after the filtration was made using DRs Watts filtering paper of $(0.5 \mu \mathrm{m})$ pore size in a funnel into a measuring cylinder. The filtrate was put in the drying oven at $50^{\circ} \mathrm{C}$ for concentration, after concentration the weight of the concentrate (extract) was $17.6 \mathrm{~g}$ then it was stored in the refrigerator at $4^{\circ} \mathrm{C}$ for further study.

\section{Isolation and Identification of Shigella dysenteriae}

Stool sample was collected and inoculated in Deoxycholate citrate agar (DCA) and Salmonella Shigella agar (SSA) and incubated at $37^{\circ} \mathrm{C}$ for 24 hour. Shigella isolates was identified base on colony size, color, texture, on Salmonella Shigella agar (SSA medium) colorless on the media. Gram stain, and further confirmation was done using biochemical test such triple sugar iron (TSI) MR, VP, Indole, Citrate, Urease and Motility test (Gaurav et al.,2013).

\section{Preparation of test crude extracts stock solution}

The stock solution of the whole plant crude extract was achieved by diluting $512 \mathrm{mg}$ of the extract in $1000 \mathrm{ml}$ of sterile distilled water in order to achieve $512 \mathrm{mg} . \mathrm{L}^{-1}$ concentration of extract.

\section{Assay of anti-bacterial activity of whole plant ethanol crude extract of} Phyllanthus amarus

The test organism was aseptically inoculated (approx. 1-2 x $108 \mathrm{cfu} \cdot \mathrm{mL}^{-1}$ ) on sterile Mueller Hinton agar using sterile cotton swab. Using sterile glass cork borers $(6 \mathrm{~mm}$ in diameter), wells were carefully made on the agar plate without distorting the media. Two hundred micro liters $(100 \mu \mathrm{L})$ of ethanol crude extracts of different concentration $\left(128 \mu \mathrm{g} \cdot \mathrm{mL}^{-1}, 256 \mu \mathrm{g}\right.$. $\mathrm{mL}^{-1}$ and $\left.512 \mu \mathrm{g} \cdot \mathrm{mL}^{-1}\right)$ was dispensed into the well. Cipro $5 \mu \mathrm{g} . \mathrm{mL}^{-1}$ sterile distilled water was used as positive and negative controls respectively. Plates were left on the bench for 10 minutes for crude extract to diffuse in medium. The culture plates were then incubated at $37^{\circ} \mathrm{C}$ for 24 hours. The diameter of the zones of inhibition was taken in millimeters (mm) using a metric ruler (Obiagwu et al., 2011).

Determination of Minimum Inhibitory Concentration (MIC) using Broth dilution method

Minimum inhibitory concentrations (MIC) of whole plant of Phyllanthus amarus ethanol crude extract were determined on Shigella dysenteriae using tube dilution method (Obiagwu et al., 2011). Different concentration was prepared from initial concentration512 $\mu \mathrm{g} \cdot \mathrm{mL}^{-1}\left(2 \mu \mathrm{g} . \mathrm{mL}^{-1}\right.$ to $\left.256 \mu \mathrm{g} \cdot \mathrm{mL}^{-1}\right)$. Bacterial concentration was adjusted to $0.5 \mathrm{McFarland}$ standard $\left(1-2.0 \times 10^{6} \mathrm{cfu} \cdot \mathrm{mL}^{-1}\right)$ and $1 \mathrm{ml}$ was inoculated in each test tube and incubated for $24 \mathrm{~h}$ at $37^{\circ} \mathrm{C}$. Two controls were used: one test tube with broth and test organism while the other one contained the broth only. After incubation, the tube with no turbidity next to the one showing turbidity (Microbial growth) was considered as MIC of the extract in question. All extracts that exhibited MIC of $100 \mu \mathrm{g}$. $\mathrm{mL}^{-1}$ and below were considered worth further investigation and Vice versa (Obiagwu et al., 2011).

\section{Determination of Minimum Bactericidal Concentration (MBC)}

Minimum Bactericidal Concentration was determined according to the method described by (Obiagwu et al., 2011). Using a sterile wire loop $(0.01 \mathrm{~mL})$ samples were picked from the broth dilution that didn't show growth (physical turbidity) and inoculated on freshly prepared Mueller Hinton agar and incubated at $37^{\circ} \mathrm{C}$ for 24 hours. The MBC was determined as the lowest concentration of the extract that allowed less than $0.1 \%$ of the original inoculums of $5 \times 10^{5} \mathrm{cfu} \cdot \mathrm{mL}^{-1}$ to grow. The plate that shows no growth of the microorganism was considered as the Minimum Bactericidal Concentration (MBC)

\section{Data analysis}

The data collected was entered into Excel. All experiment was done in triplicate and the results were presented as Mean \pm SEM. Data was analyzed using STATA v14. One way ANOVA test was used to compare between different concentration of whole plant crude ethanol crude extract and positive control and $\mathrm{p}$ value $\leq 0.05$ was considered statistically significant.

\section{RESULTS AND DISCUSSION}

The use of medicinal plants as alternative medicine is given more attention worldwide (Flora and Folasade, 2008; WHO, 2017). The percentage yield obtained was $4.7 \%$ from $375 \mathrm{~g}$ whole plant powder of Phyllanthus amarus used for extraction using $70 \%$ ethanol. The antibacterial activity of whole plant of Phyllanthus amarus ethanol crude extract was determined by agar well diffusion method and diameter zones of inhibition were measured in $\mathrm{mm}$. The mean and standard error mean zone of inhibition of different concentration $\left(128 \mu \mathrm{g} \cdot \mathrm{mL}^{-1}\right.$, $256 \mu \mathrm{g} \cdot \mathrm{mL}^{-1}$, and $512 \mu \mathrm{g} . \mathrm{mL}^{-1}$ ) the whole plant of Phyllanthus amarus ethanol crude extract against Shigella dysenteriae ranged from $11.5 \pm 0.5$ to $13.5 \pm 0.5 \mathrm{~mm}$, while the positive control had $24.5 \pm 0.5 \mathrm{~mm}$ (Table 1). There was no activity observed from negative control (sterile distilled water). The comparison between different concentration of whole plant crude extract and positive control using one way ANOVA showed significant different $(\mathrm{p}<0.05)$. The ability of the extract to showed antibacterial activity against Shigella dysenteriae could be due to the presence of phytochemical property of the plant (tannins, sapoins, cardiac glycosides and alkaloids) as reported by (Flora and Folasade, 2008). Furthermore, Ogunjobi and Abiala, 2013 also reported the presence of steroids, flavonoid, alkaloids, tannins, phylobatannins and phenol from aqueous and ethanol crude extract leaf of Phyllanthus amarus. These compounds have been reported to have effect on bacterial cell wall including Gram negative bacteria which have complex cell wall due to the high content lipid compound. The mean and standard error mean zone of inhibition obtained from this study was high than those reported by Flora and Folasade, 2008; Ogunjobi and Abiala,2013 from the leaf crude extracts (cold, hot water and ethanol) of Phyllanthus amarus against Salmonella typhi which is also Gram negative bacteria. Ogunjobi and Abiala, 2013 reported higher men and standard error mean zone of inhibition of water and ethanol crude extracts leaf of Phyllanthus amarus against Salmonella typhi and Escherichia coli which are also enteric bacteria. It was observed that, the sensitivity increased with increasing concentration of the crude ethanol extract. According to Oluduro and Omoboye (2010) the antibacterial activities of most plant extracts are concentration dependent as zone of inhibition increased with increasing concentration of the extracts. Ekwenye and Elegalam (2005) and Azu and Onyeagha (2007) reported that the efficacy of most plant extracts is concentration dependent. The ability of the whole plant Phyllanthus amarus crude extract to inhibit the growth of Shigella dysenteriae could due to the presence of phytochemicals constituents of the plants which includes alkaloids, flavonoids, saponins and tannins (Umbare et al., 2009). However, Obianime and Uche (2009) reported the presence of Flavonoids, tannins, alkaloids, steroids, terpenoids, saponins and glycosides from Phyllanthus amarus in their study. Oluduro and Omoboye (2010) indicated that the presence of phytochemicals in plant extracts is a function of their antimicrobial activities against the test pathogen as they play important roles in bioactivity of medicinal plants. They further explained that phytochemicals exert antimicrobial activity through different mechanisms. Chonoko and Rufai (2011) also indicated that there was a link between the antibacterial activity exhibited by the plant extracts to the presence of steroids flavonoids, tannins, alkaloids and saponins. Tannins, for example, act by iron deprivation, hydrogen binding or specific interactions with vital proteins such as enzymes in microbial cells (Scalbert, 1991; Akinpelu et al., 2008). Herbs that have tannins as their component are astringent in nature and are used for the treatment of gastrointestinal disorders such as diarrhoea and dysentery (Dharmananda, 2003; Asquith and Butler, 1986). The test pathogen, Shigella dysenteriae was more susceptible to the ciprofloxacin $\left(5 \mu \mathrm{g} \cdot \mathrm{mL}^{-1}\right)$ as the positive control with zone of inhibition at $24.5 \pm 0.5 \mathrm{~mm}$ higher than the ethanol crude extract at all concentrations. The negative control which is the solvent used for dissolving the extract (sterile distilled water) showed no activity. The difference between the activity of the crude extract and the standard antimicrobial drug may be due to the mixtures of bioactive compounds in the crude extract which probably have antagonistic effects against the major bioactive(s) present in the crude extracts compared to the pure compound contained in the standard antibiotic ciprofloxacin. 
Table 1 Mean and standard error of the mean activity of different concentration of whole plant of Phyllanthus amarus ethanol crude extracts on Shigella dysenteriae

\begin{tabular}{lccc}
\hline $\begin{array}{l}\text { Test } \\
\text { extract/drug }\end{array}$ & $\begin{array}{c}\text { Zone of Inhibition } \\
(\mathrm{mm}) \\
\text { Mean } \pm \text { SEM }\end{array}$ & Activity Index & p value \\
\hline $128 \mu \mathrm{g} \cdot \mathrm{mL}^{-1}$ & $11.5 \pm 0.5$ & 0.47 & \\
$256 \mu \mathrm{g} . \mathrm{mL}^{-1}$ & $12.5 \pm 0.5$ & 0.51 & \\
$512 \mu \mathrm{g} . \mathrm{mL}^{-1}$ & $13.5 \pm 0.5$ & 0.55 & 0.0000 \\
Ciprofloxacin & $24.5 \pm 0.5$ & 1.00 & \\
$\left(5 \mu \mathrm{g} . \mathrm{mL}^{-1}\right)$ & $0 \pm 0$ & 0.00 & \\
Distilled water & & & \\
\hline
\end{tabular}

The minimum inhibitory concentration of the whole plant of Phyllanthus amarus ethanol crude extracts against Shigella dysenteriae was determined using broth tube dilution method. The MIC of ethanol crude extract was found to be $32 \mu \mathrm{g}$. $\mathrm{mL}^{-1}$ (Table 2). Furthermore, Minimum bactericidal concentration (MBC) of whole plant of Phyllanthus amarus ethanol crude extracts against Shigella dysenteriae was determined. The MBC of the crude extract was found to be $64 \mu \mathrm{g}$. $\mathrm{mL}^{-1}$ (Table 2). For test extract whose MIC is $<100 \mu \mathrm{g}$. $\mathrm{mL}^{-1}$ is considered as good candidates to be developed into new drugs. However, the results of this study found that the MBC of the ethanol crude extract of whole plant of Phyllanthus amarus was $64 \mu \mathrm{g} / \mathrm{mL}^{-1}$. MBC is the lowest concentration of the extract that allowed less than $0.1 \%$ of the original inoculum. The crude extract is said to be bacteriostatic if the ratio of MBC: MIC is equal to 4, whereas it is said to be bactericidal when the ratio of MBC: MIC is equal to 2 (Kipre et al., 2017).

Table 2 Minimum inhibitory concentration (MIC) and Minimum Bacteriocidal concentration of Phyllanthus amarus ethanol crude extracts against Shigella dysenteriea

\begin{tabular}{|c|c|c|c|c|c|c|c|c|c|c|}
\hline \multirow[b]{2}{*}{ Type of extract } & \multicolumn{10}{|c|}{ Concentration of extracts in different test tubes $\left(\mu \mathrm{g} . \mathrm{mL}^{-1}\right)$} \\
\hline & 128 & 64 & 32 & 16 & 8 & 4 & 2 & 1 & MIC & $\mathrm{MBC}$ \\
\hline Ethanol & - & - & - & + & + & + & + & + & 32 & 64 \\
\hline Control 1 & + & + & + & + & + & + & + & + & + & + \\
\hline Control 2 & - & - & - & - & - & - & - & - & - & - \\
\hline
\end{tabular}

Key: + means there was growth, - Means there was no grow.

\section{CONCLUSION}

The crude extracts of $P$. amarus whole plant exhibited significant in-vitro antibacterial activity against Shigella dysenteriae thus indicating their positive role, and justifying the ethno medicinal use of the plant parts in traditional medicine. Further study should be carried out to test whole plant Phyllanthus amarus crude extract on different microorganisms that cause dysentery to find out its activity against them and spectrum, determine lead compound in the whole plant Phyllanthus amarus crude extract responsible for the anti-microbial activity against Shigella dysenteriae, determine the mechanism of action by which this plant crude extract act against Shigella dysenteriae.

Acknowledgments: We would like to thanks all staff of Microbiology and Pharmacognosy Laboratories of Kampala International University-Western Campus for their kind support during this research.

\section{REFERENCES}

AKINPELU, D.A., AIYEGORO, D.A. AND OKOH, A.I. 2008. In Vitro antimicrobial and Phytochemical Properties of Crude extract of Stem bark of Afzelia africana (Smith). AJB. 7(20); 3662-3667.

ALADE, P.I., IROBI, O.N. 1993. Antimicrobial activities of crude leaf extracts of Acalyphawilkensiana. $J$ Ethnopharmacol. 39; 171-174. https://doi.org/10.1016/0378-8741(93)90033-2

ASQUITH, T.N. AND BUTLER, L.G. 1986. Interaction of condensed tannins with selected proteins. Phytochemistry. 25 (7); 1591-1593. https://doi.org/10.1016/S0031-9422(00)81214-5

ATWIINE, A. K. 2007. Determination of Circulating Shigella Serotypes and their antimicrobial Susceptibility Patterns in selected Districts of Uganda. (Bachelor of Biomedical Laboratory Technology), Makerere University, Kampala.

AZU, N.C. AND ONYEAGBA, R.A. 2007. Antimicrobial properties of extracts of Allium cepa (onions) and Zingiber officinale (ginger) on Escherichia coli, and Bacillus subtilis. The Internet Journal of Tropical Medicine.3 (2); 277-286. https://doi.org/10.5580/1f5e

BHASHA, S., KONDETI R. S., SAHUKARI R., VENKATA S.G., KORIVI M., KESIREDDY, S.R. 2014. Antibacterial Activity and Phytochemical Screening of Phyllanthus niruri in Ethanolic, Methanolic and Aqueous Extracts. Int. J. Pharm. Sci. Rev. Res. 27(2); 85-89.

CENTRE FOR DISEASE CONTROL AND PREVENTION (CDC). 2017. Infectious Diseases Related to Travel. Available on https://wwwnc.cdc.gov/travel/yellowbook/2018/ infectious-diseases-related-totravel/shigellosis. Accessed5/8/2018.

CLINICAL AND LABORATORY STANDARDS INSTITUTE (CLSI) . 2009. Document M39-A3. Analysis and Presentation of Cumulative Antimicrobial Susceptibility Test Data; Approved Guideline, Third Edition. CLSI, 940 West Valley Road, Suite 1400, Wayne, Pennsylvania 19087-1898, USA.

CLINICAL AND LABORATORY STANDARDS INSTITUTE (CLSI). 2018. Document M100. Performance Standards for Antimicrobial Susceptibility Testing, 28th Edition A CLSI supplement for global application.
DHARMANANDA, S. (2003). Golinuts and the uses of tannins in Chinese Medicine. In proceedings of Institute for Traditional Medicine Portland, Oregon,USA, 25 September, 2003.

EKWENYE, U.N. AND ELEGALAM, N.N. 2005. Antibacterial activity of ginger (Zingiber officinales Roscoe) and garlic (Allium sativum L) extracts on Escherichia coli and Salmonella typhi. Journal of Molecular Medicine and Advanced Science 1(4): 41-416.

FLORA, O. AND FOLASADE, D. 2008. Antimicrobial Effect of Phyllanthus amarus and Parquetina nigrescens on Salmonella typhi. African Journal of Biomedical Research, Vol. $11 ; \quad 215 \quad$ - 219. http://dx.doi.org/10.4314/ajbr.v11i2.50712.

GAURAV, A., SINGH, S.P., GILL, J.P.S., KUMAR, R. AND KUMAR, D. 2013. Isolation and identification of Shigella spp. from human fecal samples collected from Pantnagar, India, Vet World 6(7):376-379. https://doi.org/10.1016/b978-070203481-7.50010-4

CHONOKO, U. G. AND RUFAI, A. B. 2011. Phytochemical screening and antibacterial activity of Cucurbita pepo (pumpkin) against Staphylococcus aureus and Salmonella typhi. BAJOPAS. 4(1); $145 \quad-147$ http://dx.doi.org/10.4314/bajopas.v4i1.30

KAJUMBULA, H. 2014. Antimicrobial Resistance (T. D. o. M. Microbiology, Trans.): Makerere University College of Health Science.

KIPRE, B. G., GUESSENND, N.K., KONÉ, M.W., GBONON V., COULIBALY, J. K., DOSSO, M. 2017. Antibacterial activity of the stem bark of Tieghemella Heckelii Pierre ex. A Chev against methicillin-resistant Staphylococcus aureus. BMC Complementary and Alternative Medicine. 17:170. https://doi.org/10.1186/s12906-017-1681-8.

LEGROS, D., OCHOLA, D., LWANGA, N., \& GUMA, G. 1998. Antibiotic sensitivity of endemic Shigella in Mbarara, Uganda. East Afr Med . 75(3); 160161.

MD. MURAD, H., MOHAMMAD, S. A., ACHINTO, S. AND MD. A. 2006 Antinociceptive Activity of Whole Plant Extracts of Paederia foetida. Dhaka Univ. J. Pharm. Sci. 5(1-2); 67-69.

MPAIRWE, Y. 2000. Resistance Pattern of Shigella Isolates at Naguru Medical Laboratory, Kampala (1995 and 2000) Naguru Medical Laboratory, Kampala.

OBIAGWU, I. N., OKECHALU, O.B. AND NJOKU, M.O. 2011. Studies on Antibacterial Effect of The Leaves of Phyllanthus niruri on Some Enteric Pathogens. Nig J. Biotech. 23; 22- 27 I.

OBIANIME A.W. AND UCHE F.I. 2009. The comparative effects of methanol extract of Phyllanthus amarus leaves and Vitamin E on the Sperm parameters of Male guinea pigs. Journal of Applied Sciences and Environmental Management 13(1): 37-41. https://doi.org/10.4314/jasem.v12i4.55222

ODDA, J., WAAKO, P., OBUA, C., KABASA, J. D. 2018. In vivo antiplasmodial activity and Safety of the aqueous ethanolic extract of Phyllanthus amarus Schum. and Thonn. International Journal of Pharmacy and Pharmaceutical Research. 12(3):265-280.

OGUNJOBI, A.A. AND ABIALA, M.A. 2013. Antimicrobial Activity of Senna alata and Phyllanthus amarus. Global Journal of Pharmacology 7 (2): 198-202 OLUDURO, A. AND OMOBOYE, O. 2010. In Vitro Antibacterial Potentials and Synergistic Effect of South-Western Nigerian Plant Parts Used in Folklore Remedy for Salmonella typhi infection. Nature and Science, 8(9): 52-59. 
SCALBERT, A. (1991). Antimicrobial Properties of tannins.Phytochemistry. 30: 3875-3883. https://doi.org/10.1016/0031-9422(91)83426-1

SEKAR D., KOLANJINATHAN K., SARANRAJ P., GAJENDIRAN K. 2012.

Screening of Phyllanthus amarus, Acalypha indica and Datura metel for its antimicrobial activity against selected pathogens. International Journal of Pharmaceutical \& Biological Archives; 3(5): 1231-1235.

SENJOBI, C.T., ETTU, A. O. AND OTUJO, C.O. 2017. Antibacterial and antifungal activities of leaf extracts of Phyllanthus amaru Schum and Thonn. Journal of Pharmacognosy and Phytotherapy. Vol. 9(1), pp. 6-10. https://doi.org/10.5897/JPP2013.0261.

UGANDA NATIONAL ACADEMY OF SCIENCES (UNAS) 2015. “Antibiotic Resistance in Uganda: Situation Analysis and Recommendations, ISBN: 9789970-424-10-8. A4 Lincoln House Makerere University P.O. Box 23911, Kampala, Uganda, 2015.https://cddep.org/wp-content/uploads/2017/08/garpuganda sa.pdf. accessed

20/9/2016.

https://doi.org/10.20319/pijss.2018.41.477493

UMBARE, R. P., MATE1, G. S., JAWALKAR, D.V., PATIL, S. M. AND

DONGARE, S. S. 2009. Quality evaluation of Phyllanthus amarus (Schumach) leaves extract for its hypolipidemic activity. Biology and Medicine 1 (4): 28-33.

WHO 2017. WHO guidelines on good herbal processing practices (GHPP) for herbal medicines. Available

http://www.who.int/medicines/areas/quality_safety/quality_assurance/V-

2ndGlobalReview-RevisedDraft-WHO-GHPP-March2017.pdf. Accessed $9 / 8 / 2018$ 